\title{
Development of Reasonable Inquiry-Based Learning on Social Cloud Model to Enhance Undergraduate Students' Critical Thinking
}

\author{
Patamaporn Thaiposri*, Pallop Piriyasurawong \\ King Mongkut's University of Technology North Bangkok, Bangkok, Thailand. \\ * Corresponding author. Email: p.thaiposri@gmail.com \\ Manuscript submitted May 21, 2016; accepted August 11, 2016. \\ doi: 10.17706/ijeeee.2016.6.3.162-174
}

\begin{abstract}
The purposes of this research study were: 1) to develop the reasonable inquiry-based learning on social cloud model (RIBL on Social Cloud Model) to enhance undergraduate students' critical thinking, and 2) to evaluate the appropriateness of the RIBL on Social Cloud Model. The research methodology was divided into two steps. The first step was to develop the RIBL on Social Cloud Model to enhance undergraduate students' critical thinking and the second step was to evaluate the appropriateness of the RIBL on Social Cloud Model. The samples in this research study consisted of five purposive-selected experts in instructional design, inquiry-based learning, social network, cloud computing and critical thinking. The research instruments included the RIBL on Social Cloud Model to enhance undergraduate students' critical thinking and the appropriateness evaluation form. Data were analyzed using mean $(\bar{x})$ and standard deviation (S.D.). The research findings were as follows: 1) the RIBL on Social Cloud Model to enhance undergraduate students' critical thinking consisted of four components: 1.1) analysis of crucial factors, 1.2) preparation before learning, 1.3) reasonable inquiry-based learning on social cloud process, 1.4) measurement and evaluation, and 2) overall, the samples perceived that the RIBL on Social Cloud Model was highly appropriate and applicable to real practice.
\end{abstract}

Key words: Critical thinking, inquiry-based learning, social cloud.

\section{Introduction}

Information and communication technology (ICT) has been envisioned to be an important force that will drive Thai society towards a community of knowledge and intelligence, sustainable economic development, and equality [1]. This idea was introduced into the National ICT Policy Framework 2011-2020: ICT 2020, which later led to the development of the Framework Gor-3 under Strategy No.6 on the Development and Application of ICT to Support Smart-Learning (also known as "Life-Long Learning"). The Framework employs several strategies and measures to promote the creation and application of innovation and digital media in order to enhance learning.

Partnership for $21^{\text {st }}$ Century Skills has incorporated the vision on learning into the $21^{\text {st }}$ Century Student Outcomes and Support Systems, which aim to build learning and innovative skills that are essential to working life [2]. One very important skill is critical thinking, which is also a tenet under Chapter Four of the National Education Act, B.E. 2542. The provision includes education management guidelines, which emphasizes skills practice, thinking processes, management systems, confrontation of problems within 
various situations, and the application of knowledge in order to prevent and solve problems. In addition, the provision suggests that students are to learn from real-life experience and have hands-on actual practice that requires them to critically think through the situation at hand. Students are also encouraged to read and learn continuously [3].

Critical thinking is reasonable reflective thinking focused on deciding what to believe or do [4]. Therefore, the growth of critical thinking skills is one of the main goals that every post-secondary institution should achieve [5]. In order to lay down a definition, critical thinking is a form of advanced thinking skill that requires the processing of principles and reasoning. Such a form of thinking is crucial for effective learning and livelihood today. Critical thinking is a combination of three skills: analytical thinking, logic thinking and reasoning, and fact-finding [6]. In order to achieve conclusive decision-making, critical thinking has a close relationship with logical reasoning in the process of finding the best reasonable solution based on available information and evidence [7]. Development of critical thinking may arise in the problem-solving process that is carried on in difficult situations or problematic circumstances, which are too complex to resolve in a short period of time, but that may be settled through the processing of relevant information, knowledge and opinion as a basis of further analysis, review and evaluation in various dimensions in order to reach thorough and reasonable outcome[8]. The requirement that students participate in an activity and experience directly from it, perhaps through the use of tangible instructional media, will stimulate students to think critically. In addition, group learning and participation is a great way to help students express their idea to other members within the group. This is useful in terms of encouraging students to push forward their idea, allowing them to realize its benefits and flaws, and finally making them more cautious in their systematic thinking [9].

An inquiry-based learning process is a learning model that focuses on the development and confrontation of problems or actual situations by adopting critical thinking as a means to review problems, and explore and figure out the cause of the problems [10]. Students that adopt inquiry-based learning tend to develop the ability to think critically better than students in the general education management system [11]. The BSCS 5E Instructional Model is an example of inquiry-based learning which comprises five learning phases: 1) engagement, 2) exploration, 3) explanation, 4) elaboration, and 5) evaluation [12].

ICT and social network have recently become very effective tools that help improve teaching methods and supports critical thinking skill [5]. Education management in Thailand has been quite responsive to social and technological change by far. Social network has been used and applied to teaching. Teachers and students may share knowledge on social network [13]. By definition, social network is a site or service that allows people to connect with each other, to inform others about events and activities. Users may share news, photos, videos and other items of interest. It is a new way of communication and information sharing that has become very popular, especially among younger generations [14].

Another internet-based learning tool is cloud computing. It contributes to the growing number of useful services that are now available on the internet and provides a wide range of services useful to students and teachers, such as direct access to different academic resources, research applications and higher education tools. Cloud computing also enables users to conveniently access a network of resources such as servers, storage applications and services [15]. Cloud computing can help educational institutions overcome challenges in the form of cost reduction, enabling quick and effective communication, security and privacy and ensuring flexibility and accessibility[16].

From the context above, it is found that undergraduate students' critical thinking abilities could be enhanced by using the reasonable inquiry-based learning on social cloud. This research papers introduces the development of the reasonable inquiry-based learning on social cloud model (RIBL on Social Cloud Model) to enhance undergraduate students' critical thinking in the actual teaching setting. 
In this study, social cloud is a social network that was developed using cloud computing service (PaaS). It allows users to connect, interact, communicate, share opinions, share data and share experience to each other.

\section{Purpose of the Study}

1) To develop the reasonable inquiry-based learning on social cloud model (RIBL on Social Cloud Model) in order to enhance undergraduate students' critical thinking.

2) To evaluate the appropriateness of the RIBL on Social Cloud Model to enhance undergraduate students' critical thinking.

\section{Method}

\subsection{Scope of the Study}

The population in this research study consisted of experts in instructional design, inquiry-based learning, social network, cloud computing and critical thinking.

The sample comprised five experts in instructional design, inquiry-based learning, social network, cloud computing, and critical thinking. This sample held a doctoral degree and at least three years of experience in related fields. A purposive selection method was used.

\subsection{Variables of the Research}

The independent variable was the RIBL on Social Cloud Model to enhance undergraduate students' critical thinking and the dependent variable was the results of the learning model appropriateness evaluation.

\subsection{Research Methodology}

1) The aim was to develop the RIBL on Social Cloud Model to enhance undergraduate students' critical thinking.

- Relevant articles and research papers were analyzed and synthesized.

- Five experts were interviewed to gather and analyze data about learning activities. These experts were asked to provide data on students' ICT literacy for learning, learning styles and cognitive styles.

- Research instruments were designed as follows: 1) the RIBL on Social Cloud Model to enhance undergraduate students' critical thinking and, 2) the appropriateness evaluation form.

- The learning model was verified and the five purposive-selected experts filled in the appropriateness evaluation form.

2) The aim was to evaluate the appropriateness of the RIBL on Social Cloud Model to enhance undergraduate students' critical thinking.

- The learning model was evaluated by the five purposive-selected experts.

- The learning model was modified based on the advice of the experts.

- The learning model was demonstrated using diagrams and a written essay.

- The results of the appropriateness evaluation were analyzed using mean $(\bar{x})$ and standard deviation (S.D.). Five criteria for evaluation were considered using Likert scales anchored with the terms highest, high, moderate, low and lowest.

\section{Results}

1) Reasonable inquiry-based learning on social cloud model (RIBL on Social Cloud Model) to enhance undergraduate students' critical thinking is illustrated in Fig. 1. 
Reasonable Inquiry-Based Learning on Social Cloud Model (RIBL on Social Cloud Model) to Enhance Undergraduate Students' Critical Thinking

\section{1) Analysis of crucial factors}

1.1) Analysis subject-by-subject and content-by-content

1.2) Analysis readiness of students

1.3) Analysis of the readiness of instructors

1.4) Analysis of the factors that support learning

\section{2) Preparation before learning}

2.1) Provide orientation to students

2.2) Register students on the RIBL on Social Cloud System

2.3) Measure pre-learning achievement

2.4) Measure critical thinking abilities prior to teaching

3) RIBL on Social Cloud Process to enhance undergraduate students' critical thinking

3.1) Preparation step

3.1.1) Building the learning environment

3.1.2) Build positive relationship with students

3.1.3) Examine students' prior knowledge

3.2) Reasonable inquiry-based learning step

3.2.1) Engagement

3.2.2) Exploration

3.2.3) Explanation

3.2.4) Elaboration

3.2.5) Evaluation

3.3) Reflective Step

3.3.1) Students and instructor engage in a discussion that reflects issues arising from the current teaching, which may be adopted as a guideline for future improvement.

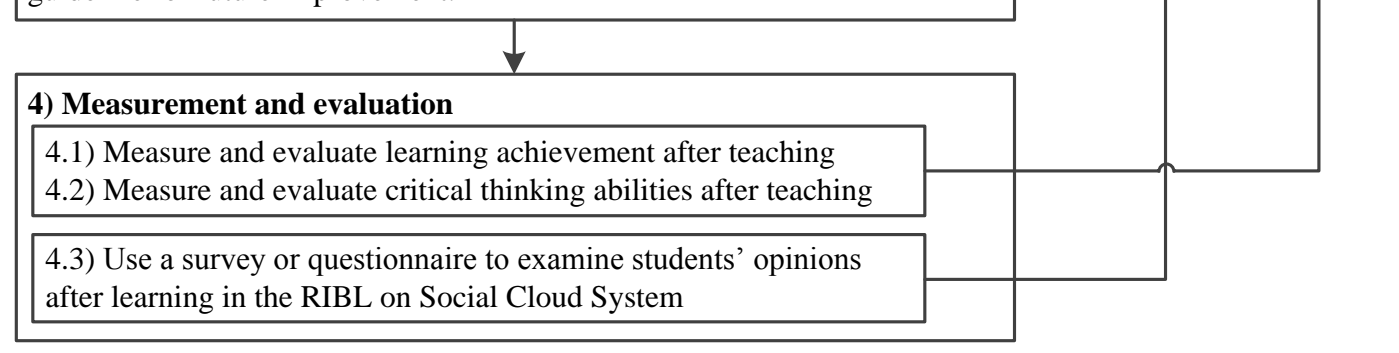

Fig. 1. RIBL on social cloud model to enhance undergraduate students' critical thinking.

The RIBL on Social Cloud Model that aims at enhancing undergraduate students' critical thinking comprises four components as follows:

\subsection{Analysis of Crucial Factors}

- Analysis subject-by-subject and content-by-content in order to establish goals, the design learning management plan, design practical activities, establish criteria for measurement and evaluation, prepare learning tools and supporting instruments.

- Analysis readiness of students' knowledge and ability to use ICT to search for information via the internet and to create citations, knowledge upon the quality of information based on its accuracy, being up-to-date, capability to serve the need, completeness, verifiability [17], and the ability to use word processing, spreadsheets, presentation software, and cloud computing.

- Analysis of the readiness of instructors regarding knowledge and understanding in reasonable inquiry-based learning process and student-centered learning, which requires that the instructor 
acts as a facilitator who provides suggestions or recommendations on the learning topic to students, and the ability to use cloud computing.

- Analysis of the factors that support learning such as a suitable learning environment in a room where group activities can be pursued, and hardware, software and internet availability. These are fundamental factors that strengthen learning through reasonable inquiry-based learning systems on social cloud.

\subsection{Preparation Before Learning}

- Provide orientation to students that would give them information about the courses to be taught, the content of the courses, the course outline, learning objectives, learning methods, learning activities and the criteria of measurement and evaluation.

- Register students on the reasonable inquiry-based learning on social cloud system and begin practical exercises.

- Measure pre-learning achievement by using multiple-choice questions and inform students regarding the result.

- Measure critical thinking abilities prior to teaching by using multiple-choice questions that evaluate critical thinking abilities, which are newly designed according to seven criteria on critical thinking abilities [18] as follows:

a) Be able to accurately establish ultimate goals for the thinking process.

b) Be able to capture issues in the thinking process.

c) Be able to process information including facts and opinions on the issues, either in depth, horizontally or vertically.

d) Be able to analyze and select information to support the thinking process.

e) Be able to evaluate the quality of information.

f) Be able to apply reasoning in the process of analyzing information and introducing reasonable answers/options.

g) Be able to choose the options and/or provide opinions regarding the issue at hand.

Students are to be informed of the measurement and evaluation results.

\subsection{Reasonable Inquiry-Based Learning on Social Cloud Process to Enhance Undergraduate Students' Critical Thinking}

The RIBL on Social Cloud Process comprises three main steps as follows:

- Preparation step

a) Building the learning environment

Role:

Instructor creates a learning environment with tranquility, order and simplicity.

Instructor allows students to gain hands-on experience and learn directly from actual situations.

Students switch to a different learning group every week.

\section{Expected goal:}

Students stay focused and are ready to learn.

Students gain hands-on experience and are involved in their learning by thinking and doing simultaneously.

Students are able to adjust to the teamwork environment.

b) Build positive relationship with students

Role:

Instructor acts as a facilitator in the learning process. Instructor should be of a good character, reflective 
of good personality, moral, knowledgeable, fair and kind.

\section{Expected goal:}

Students trust the instructor and are willing to open up to the instructor.

Instructor is capable of assisting students in problematic situations.

c) Examine students' prior knowledge

\section{Role:}

Instructor explains the learning activities plan for the week.

Students take a pre-test in order to assess their prior knowledge.

Instructor sets out teaching plans that suits students' prior knowledge.

\section{Software modules on social cloud:}

Module introducing learning activities plan.

Module pre-testing.

\section{Expected goal:}

Students are informed about the learning activities plan.

Students are driven to self-improve after receiving the result of their pre-test.

Instructor has information regarding students' background knowledge and is able to plan his/her teaching accordingly.

- $\quad$ Reasonable inquiry-based learning step

\section{a) Engagement}

\section{Role:}

Instructor introduces problems, issues, and case studies relevant to the lesson in order to encourage engagement.

Instructor, together with the students, establishes problems or issues for the respective teaching.

\section{Software modules on social cloud:}

Module discussion board.

\section{Expected goal:}

Students pay attention to the problems, issues, or case studies introduced by the instructor.

Students have critical thinking abilities (1), (2), (3), (5) [18].

b) Exploration (by using group investigation: GI technique)

\section{Role:}

Instructor divides students into groups (3-5 members in each group) as he/she sees appropriate. The members of each group may have different background knowledge, based on the result of their pre-test.

Students split roles and responsibilities among group members by emphasizing the role and responsibilities that may actually be exercised such as the leader, information compiler, and presenter.

Instructor recommends sources of information that may be used to solve the problems or issues of interest. Students discuss the information they find within their group or between groups.

Students discuss in order to digest information regarding the problems and issues spotted and try to establish possible common hypotheses.

Students try to prove the established hypotheses by employing various methods such as information searching, learning by doing, field experimentation, and mock practice.

Students record information found in an orderly manner by clearly citing the sources.

Students bring the outcome to discussion in order to test the hypotheses.

\section{Software modules on social cloud:}

Module managing of students.

Module discussion board. 
Module recording information and sources.

Module chat room.

\section{Expected goal:}

Students are able to adjust themselves to the group work setting.

Students are responsible for the work/task assigned to them.

Students are able to search information from the sources introduced by the instructor.

Students have critical thinking abilities (2), (3), (4), (5), (6) [18].

c) Explanation

\section{Role:}

Students analyze the information that they record, and prepare information in an appropriate form such as tables, graphs, diagrams, etc.

Students build their own body of knowledge through explanation of their ideas, citation of information sources, as well as showing evidence, and demonstrate whether the result of the practice is consistent with the established hypotheses.

Students present the result of their practical finding to the instructor and their group members.

Instructor poses questions to encourage students to establish tendency and relationship of information available.

Instructor poses leading questions that induce students to find the conclusion of their practice and discuss this conclusion with relevant reasoning. This encourages students to review the consistency between the result of their practice and the hypotheses.

Instructor and students discuss, exchange ideas and provide feedback on the explanation of each group in order to clarify the learning.

Students link their prior knowledge to the new knowledge and are able to explain their answers by applying prior knowledge.

\section{Software modules on social cloud:}

Module recording of information and sources.

Module building of a new body of knowledge.

Module presenting of the result of practice finding.

Module discussion board.

Module chat room.

\section{Expected goal:}

Students have critical thinking abilities (3), (4), (5), (6), (7) [18].

d) Elaboration

\section{Role:}

Instructor arranges activities or unprecedented situations where students may apply their new knowledge.

Students elaborate on their new knowledge by discussing and expressing additional ideas regarding the new knowledge for clarity.

Students present the link between their prior knowledge and the new knowledge by using various methods such as models or diagrams.

Instructor encourages students to do further research on their issue of interest.

Students present information and methods used to derived information.

\section{Software modules on social cloud:}

Module discussion board.

Module recording of information and sources. 
Module building of new body of knowledge.

Module introducing the link between prior knowledge and new knowledge.

Module introducing information and methods deriving information.

\section{Expected goal:}

Students apply new knowledge in the activities or mock situations arranged by the instructor.

Students have critical thinking abilities (2), (3), (4), (5), (6), (7) [18].

e) Evaluation

\section{Role:}

Students evaluate their progress in learning.

Students evaluate the work performance of other group members.

Students take a post-test in order to evaluate learning, according to the learning objectives.

Instructor evaluates his/her progress in students' learning based on their performance.

\section{Software modules on social cloud:}

Module evaluating self-progress in learning

Module evaluating work performance of group members

Module post-testing

Module evaluating progress in students' learning based on their performance

\section{Expected goal:}

Students see their own strengths and weaknesses and make an improvement.

Students are informed regarding the result of their performance, as evaluated by the members of their group, and make an improvement.

Students have critical thinking abilities (1), (2), (3), (4), (5), (6), (7) [18].

Students are informed regarding the result of their performance, as evaluated by the instructor, and make an improvement.

\section{Role:}

- $\quad$ Reflective Step

a) Students and instructor engage in a discussion that reflects issues arising from the current teaching, which may be adopted as a guideline for future improvement.

Software modules on social cloud:

Module discussion board.

\section{Expected goal:}

Instructor and students bring opinions and recommendations to apply to the next stage of teaching for improvement.

\subsection{Measurement and Evaluation}

- Measure and evaluate learning achievement after teaching by using an evaluation form consisting of multiple-choice questions. Students are to be informed of the evaluation result.

- Measure and evaluate critical thinking abilities after teaching by using an evaluation form consisting of multiple-choice questions newly created according to critical thinking criteria [18]. Students are to be informed of the evaluation result.

- Use a survey or questionnaire to examine students' opinions after learning in the reasonable inquiry-based learning on social cloud system. Data collected from the survey will be analyzed for the improvement of future learning process.

2) Evaluation of the effectiveness of the reasonable inquiry-based learning on social cloud model (RIBL on Social Cloud Model) to enhance undergraduate students' critical thinking 
Table 1. Results of the Appropriateness Evaluation of Reasonable Inquiry-Based Learning on Social Cloud Model (RIBL on Social Cloud Model) to Enhance Undergraduate Students' Critical Thinking

Evaluation Lists

Level of

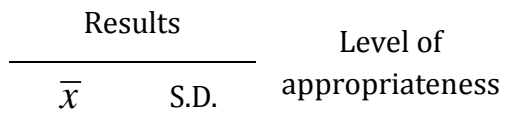

Components of the RIBL on Social Cloud Model to enhance undergraduate students' critical thinking

1) Analysis of crucial factors

1.1) Analyze subject-by-subject and content-by-content

1.2) Analyze readiness of students

1.3) Analyze readiness of instructors

1.4) Analyze factors that support learning

2) Preparation before learning

2.1) Provide orientation to students

2.2) Register students on the RIBL system on social cloud

2.3) Measure pre-learning achievement

2.4) Measure critical thinking abilities prior to teaching

3) RIBL on Social Cloud Process to enhance undergraduate students' critical thinking

3.1) Preparation step

3.1.1) Build learning environment

3.1.2) Build positive relationship with students

3.1.3) Examine students' prior knowledge

3.2) Reasonable inquiry-based learning step

3.2.1) Engagement

3.2.2) Exploration

3.2.3) Explanation

3.2.4) Elaboration

3.2.5) Evaluation

3.3) Reflective Step

3.3.1) Students and instructor engage in a discussion that reflects issues arising from the current teaching, which may be adopted as a guideline for future improvement.

4) Measurement and evaluation

4.1) Measure and evaluate learning achievement after teaching

4.2) Measure and evaluate critical thinking abilities after teaching

4.3) Examine students' opinion after learning in the RIBL on Social Cloud System

\begin{tabular}{|c|c|c|}
\hline 4.65 & 0.50 & Highest \\
\hline 4.40 & 0.55 & High \\
\hline 4.80 & 0.45 & Highest \\
\hline 4.80 & 0.45 & Highest \\
\hline 4.60 & 0.55 & Highest \\
\hline 4.45 & 0.55 & High \\
\hline 4.40 & 0.55 & High \\
\hline 4.60 & 0.55 & Highest \\
\hline 4.40 & 0.55 & High \\
\hline 4.40 & 0.55 & High \\
\hline 4.64 & 0.49 & Highest \\
\hline 4.40 & 0.52 & High \\
\hline 4.40 & 0.55 & High \\
\hline 4.20 & 0.45 & High \\
\hline 4.60 & 0.55 & Highest \\
\hline 4.72 & 0.49 & Highest \\
\hline 4.80 & 0.45 & Highest \\
\hline 4.80 & 0.45 & Highest \\
\hline 4.60 & 0.55 & Highest \\
\hline 4.60 & 0.55 & Highest \\
\hline 4.80 & 0.45 & Highest \\
\hline 4.80 & 0.45 & Highest \\
\hline 4.80 & 0.45 & Highest \\
\hline
\end{tabular}

$\begin{array}{lll}4.27 & 0.48 & \text { High } \\ 4.20 & 0.45 & \text { High } \\ 4.40 & 0.55 & \text { High } \\ & & \\ 4.20 & 0.45 & \text { High }\end{array}$

$\begin{array}{llll}\text { Summary } & 4.50 & 0.50 & \text { High }\end{array}$

Note. Table 1 shows that the sample perceived that the RIBL on Social Cloud Model to enhance undergraduate students' critical thinking was highly appropriate $(\bar{x}=4.5$, S.D. $=0.5)$. 
Table 2. Results of the Appropriateness Evaluation of the RIBL on Social Cloud Model to Enhance Undergraduate Students' Critical Thinking for Apply in Real Practice

\begin{tabular}{|c|c|c|c|}
\hline \multirow{2}{*}{ Evaluation Lists } & \multicolumn{2}{|c|}{ Results } & \multirow{2}{*}{$\begin{array}{l}\text { Level of } \\
\text { appropriateness }\end{array}$} \\
\hline & $\bar{x}$ & S.D. & \\
\hline \multicolumn{4}{|l|}{ Overall } \\
\hline $\begin{array}{l}\text { - The RIBL on Social Cloud Model is appropriate for enhancing } \\
\text { undergraduate students' critical thinking }\end{array}$ & 4.60 & 0.55 & Highest \\
\hline $\begin{array}{l}\text { - The RIBL on Social Cloud Model enhances undergraduate } \\
\text { students' critical thinking }\end{array}$ & 4.60 & 0.55 & Highest \\
\hline $\begin{array}{l}\text { - The RIBL on Social Cloud Model to enhance undergraduate } \\
\text { students' critical thinking could be applied in real practice }\end{array}$ & 4.40 & 0.55 & High \\
\hline Summary & 4.53 & 0.55 & Highest \\
\hline
\end{tabular}

Note. Table 2 shows that the sample gave the highest indication that the RIBL on Social Cloud Model to enhance undergraduate students' critical thinking was applicable to real practice $(\bar{x}=4.53$, S.D. $=0.55)$.

\section{Discussion}

Certain components of the RIBL on Social Cloud Model, which are 2.1) providing orientation to students and 2.2) registering students on the RIBL on Social Cloud System, are consistent with the learning process discussed in Xu and Xu's (2011) research project; this comprises seven steps as follows: 1) introduction, 2) task definition, 3) information seeking, 4) location and access, 5) use of information, 6) synthesis, and 7) evaluation. Students are free to search for information and take advantage of the resources available. The observation finds that students are highly enthusiastic and able to design problem-solving processes and research techniques by using search engines. They have general knowledge about copyrights and are able to engage in teamwork [19].

According to the statistical results of Li (2013), the RIBL process was shown to be 'highest' appropriate and applicable to real practice, confirming that an inquiry-based learning approach is effective. The students' abilities to plan, investigate, analyze, communicate, and reflect are improved as well [20].

The RIBL on Social Cloud Process emphasizes the practice where students do research, practice, conduct experiment, and bring the results to discussion in order to test the hypotheses, exchange ideas and provide reasonable recommendations, create relevant citations and produce appropriate evidence. This is consistent with the research of Haghparast et al. (2013), which supports that seeking behavior in an e-learning environment helps improve undergraduate students' critical thinking as students may search for information while being in the e-learning environment and begin their learning from building understanding and establishing problems. They can then exercise their critical thinking skill during the information searching process, selecting and collecting relevant information for further analysis and synthesis. They may also exercise their critical thinking skills for an evaluation of performance and conflicts in order to derive the right, relevant, and accurate answer, through the use of online tools [5]. Such proposition is consistent with Goh's (2012) research that states that critical thinking emerges from the blending of ideas of different parties. The reliable ideas are reflected and synthesized and the learning process takes place when learners present their diverse views. As such, students receive new input from their peers and instructor, which they can incorporate into their reasoning and application of principles to their own experience [21].

The design of the RIBL activities was similar to the findings of Ma et al. (2011), who present five steps to facilitate students' learning as follows: 1) situating learning in an authentic context and stimulating 
students' interests in learning 2) encouraging self-directed learning 3) solving and resolving problems through collaborative learning 4) expanding learning experience through individual-based learning, and 5) presenting and assessing learning outcomes. The current research shows that students in an inquiry-based class achieve better content knowledge and technical skills than those in a didactic instruction class. Most students express positive and favorable feelings and attitudes towards their learning, learning abilities and the online learning environment [22].

The idea that supports the integration of ICT into inquiry-based learning comes from Ma et al. (2011), who state that most students who experience learning through the issue-spotting process in the online environment have positive feelings and attitudes towards learning [22]. This finding is consistent with the research of Eteokleous and Eteokleous (2012), which supports that cloud computing facilitates communication, team-working, sharing between students and instructor within the "community of inquiry," and is a key to success in learning [23]; it is also consistent with Ractham and Firpo's (2011) research, which supports that social network is a tool to support leaning at the post-secondary level. It facilitates students' sharing and building of knowledge within an informal learning environment [24].

\section{Acknowledgment}

This research is partly funded by the research grant for Doctoral dissertation, Graduate School, King Mongkut's University of Technology North Bangkok.

\section{References}

[1] Ministry of Information and Communication Technology. (2011). National ICT Policy Framework 2011-2020: $\quad$ ICT 2020. Retrieved December 3, 2014, from http://www.oic.go.th/FILEWEB/CABINFOCENTER3/DRAWER088/GENERAL/DATA0000/00000498.P $\mathrm{DF}$

[2] Partnership for 21st century skills. (2011). Framework for 21st Century Learning. Retrieved December 3, 2014, from http://www.p21.org/storage/documents/1._p21_framework_2-pager.pdf

[3] Office of the Council of State. (1999). National Education Act (B.E. 2542). Retrieved December 3, 2014, from http://www.moe.go.th/main2/plan/p-r-b42-01.htm

[4] Ennis, R.H. (1993). Critical Thinking Assessment. Retrieved February 2, 2015, from http://www3.qcc.cuny.edu/WikiFiles/file/Ennis\%20Critical\%20Thinking\%20Assessment.pdf

[5] Haghparast, M., et al. (2013). Modeling an e-learning tool to cultivate critical thinking in students based on information needs and seeking behavior. Proceeding of 2013 IEEE International Conference on Teaching, Assessment and Learning for Engineering (TALE) (pp. 521-526).

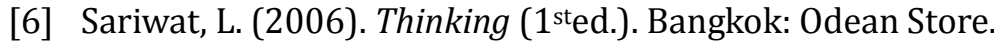

[7] Moonkam, S. (2004). Teaching Strategies of Critical Thinking (1sted.). Bangkok: Parbpim.

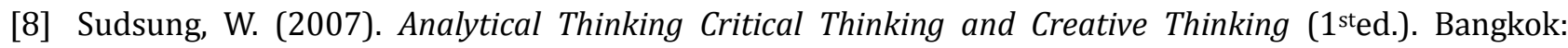
Chomromdek.

[9] Susaoraj, P. (2008). Thinking Development (2nded.). Bangkok: 9119 Technic Printing.

[10] Janpong, S., et al. (2012). Effects of Collaborative Game Based e-Learning using Inquiry Based Learning Process and Discovery Learning Based Process upon Analytical Thinking Skills of Pratom 6 Students with Difference Learning Styles. Retrieved May 18, 2015, from http://www.tci-thaijo.org/index.php/edujournal_nu/article/view/9335/8447

[11] Wongkam, N., et al. (2012). The Effects of Using the 7Es Learning Management Approach Emphasizing Critical Thinking Activities in the Topic of Homeostasis on Learning Achievement and Critical Thinking Ability of Mathayom Suksa IV Students at Piriyalai Changwat Phara School in Phare Province. Retrieved 
http://www.stou.ac.th/thai/grad_stdy/Masters/\%E0\%B8\%9D\%E0\%B8\%AA\%E0\%B8\%AA/research /2nd/FullPaper/SS/Oral/O-SS\%20022\%20\%E0\%B8\%99\%E0\%B8\%B2\%E0\%B8\%87\%E0\%B8\%99\% E0\%B8\%87\%Е0\%B8\%99\%Е0\%B8\%B2\%Е0\%B8\%8E\%20\%20\%Е0\%B8\%A7\%Е0\%B8\%87\%Е0\%B8 \%84\%E0\%B9\%8C\%E0\%B8\%84\%E0\%B8\%B3.pdf

[12] Bybee, R. W., et al. (2006). The BSCS 5E Instructional Model: Origins and Effectiveness. Retrieved December 3, 2015, from http://bscs.org/sites/default/files/_legacy/BSCS_5E_Instructional_Model-Full_Report.pdf

[13] Thaisit, P. (2012). Social Network Is the Way Chosen at Higher Education in Thailand. Retrieved March 10, 2015, from http://www.inded.kmitl.ac.th/journal/images/stories/year11_3/vol11_03_v01.pdf

[14] Poore, M. (2013). Using Social Media in the Classroom a Best Practice Guide (1sted.). U.K.: SAGA Publication.

[15] Mell, P., \& Grance, T. (2011). The NIST Definition of Cloud Computing. Retrieved January 20, 2016, from http://nvlpubs.nist.gov/nistpubs/Legacy/SP/nistspecialpublication800-145.pdf

[16] Alshuwaier, F. A., et al. (2012). Applications of cloud computing in education. Proceeding of 2012 8th International Conference on Computing and Networking Technology (ICCNT) (pp. 26-33).

[17] Yuangthong, S. (2014). Fundamentals of Computer and Information Technology (2nded.). Bangkok: Provision.

[18] Khammanee, T. (2012). Principles of Teaching: Body of Knowledge for Effective Learning Process Management (16 ${ }^{\text {the }}$.). Bangkok: Chulalongkorn University Press.

[19] Xu, G., \& Xu, X. (2011). Qualitative research of web-based collaborative inquiry learning in higher education. Proceeding of 2011 International Conference on Electrical and Control Engineering (ICECE) (pp. 6710-6714).

[20] Li, X. (2013). Learning from industry by using an inquiry based learning approach. Proceeding of 2013 IEEE Frontiers in Education Conference (pp. 943-949).

[21] Goh, W. W. (2012). The use of wiki to facilitate critical thinking. Proceeding of IEEE International Conference on Teaching, Assessment, and Learning for Engineering (TALE).

[22] Ma, C., et al. (2011). An inquiry-based learning approach on a educational technology course. Proceeding of 2011 IEEE International Symposium on IT in Medicine and Education (ITME) (pp. 422-424).

[23] Eteokleous, N., \& Eteokleous, D. (2012). Community of inquiry developed through cloud computing for MIS courses. Proceeding of 2012 IEEE Global Engineering Education Conference (EDUCON) (pp. 1-4).

[24] Ractham, P., \& Firpo, D. (2011). Using social networking technology to enhance learning in higher education: A case study using Facebook. Proceedings of the $44^{\text {th }}$ Hawaii International Conference on System Sciences (pp. 1-10).

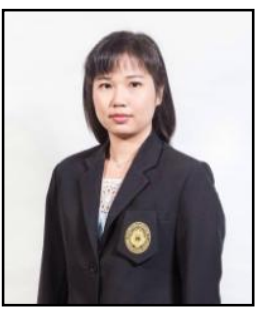

Patamaporn Thaiposri is Ph.D. student from the Department of Information and Communication Technology for Education, Faculty of Industrial Education at King Mongkut's University of Technology North Bangkok (KMUTNB), Thailand. She graduated with a Bachelor of Science (Computer Science) in 2005 from Chandrakasem Rajabhat University, Thailand. Upon completion of her Bachelor degree, she attended the Master of Science program (Information Technology) at King Mongkut's Institute of Technology Ladkrabang (KMITL), Thailand and graduated in 2009. At the present, she is a lecturer in the division of Information Technology, Faculty of Science and Technology, Nakhon Pathom Rajabhat University, Thailand. 


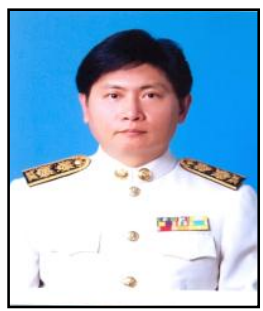

Pallop Piriyasurawong is an assistant professor at Division of Information and Communication Technology for Education, Faculty of Technical Education, King Mongkut's University of Technology North Bangkok (KMUTNB), Thailand. He received the B.Ed. degree in education technology (honor degree). He obtained his M.Ed. degree in educational technology, and received the Ph.D. degree in education technology, Cert. in energy conservation, Japan. He is an executive director of Ph.D. Program in information and communication technology for education, and the master of Science Department of Information and Communications Technology for Education, Faculty of Technical Education, King Mongkut's University of Technology North Bangkok (KMUTNB), Thailand. 